\title{
Pengaruh pemberian limbah sereh wangi (Cymbopogon nardus) fermentasi sebagai substitusi pakan basal terhadap kualitas semen domba ekor tipis
}

\author{
Elmy Mariana *, Nanda Riski, Cut Intan Novita \\ Program Studi Peternakan, Fakultas Pertanian, Universitas Syiah Kuala, Banda Aceh, 23111 \\ *Correspondence: elmy_mariana@unsyiah.ac.id
}

Received: December 16 ${ }^{\text {th }}, 2019$; Accepted: June 26 ${ }^{\text {th }}, 2020$; Published online: November $26^{\text {th }}, 2020$

\begin{abstract}
Abstrak
Tujuan: Penelitian ini bertujuan untuk mengetahui pengaruh penggunaan limbah sereh wangi fermentasi sebagai substitusi pakan basal selama 14 hari terhadap kualitas semen domba ekor tipis. Metode: Sebanyak 4 ekor domba ekor tipis jantan berumur antara 18-24 bulan dengan bobot badan $25,4 \pm 1,01 \mathrm{~kg}$ digunakan dalam penelitian ini. Penelitian menggunakan rancangan bujur sangkar latin (RBSL) yang terdiri dari 4 perlakuan dan 4 ulangan. Perlakuan P0 = Kontrol (tanpa substitusi limbah sereh wangi fermentasi), P1 = substitusi limbah sereh wangi fermentasi 10\%, P2 = substitusi limbah sereh wangi fermentasi $20 \%$ dan P3 = substitusi limbah sereh wangi fermentasi $30 \%$. Parameter yang diamati adalah kualitas makroskopis semen yang terdiri atas volume, warna, bau, $\mathrm{pH}$ dan konsistensi spermatozoa serta kualitas mikroskopis semen yang terdiri atas konsentrasi, gerakan massa dan motilitas spermatozoa.

Hasil: Hasil penelitian menunjukkan bahwa substitusi limbah sereh wangi fermentasi dengan konsentrasi yang berbeda tidak berpengaruh nyata terhadap kualitas semen. Volume, warna, bau, $\mathrm{pH}$, konsistensi, konsentrasi, gerakan massa dan motilitas spermatozoa yang dihasilkan domba ekor tipis yang diberi limbah sereh wangi fermentasi sebagai substitusi pakan basal di kategorikan baik. Kesimpulan: Kesimpulan penelitian ini penggunaan limbah sereh wangi fermentasi sebagai substitusi pakan basal selama 14 hari perlakuan tidak menyebabkan penurunan kualitas semen yang dihasilkan domba ekor tipis.
\end{abstract}

Kata Kunci: Kualitas semen; Limbah; Sereh wangi

Abstract

Objective: This study aimed to determine the effect of the use of fermented citronella (Cymbopogon nardus) waste as a substitute for basal feed for 14 days on the quality of thin-tailed ram semen.

Methods: A total of 4 Thin-Tailed Ram aged between 18-24 months with a body weight of $25.4 \pm 1.01$ $\mathrm{kg}$ were used in this study. The study used a latin square design (RBSL) consisting of 4 treatments and 4 replications. $\mathrm{P} 0=$ control (without substitution of fermented citronella), $\mathrm{P} 1=$ substitution of $10 \%$ fermented citronella waste, P2 = substitution of $20 \%$ fermented citronella waste, and P3 = substitution of $30 \%$ fermented citronella waste. The parameters observed were macroscopic quality of semen consisting of volume, color, odor, $\mathrm{pH}$ and consistency. While the microscopic quality of 
semen consisted of spermatozoa concentration, mass sperms motility, and individual spermatozoa motion.

Results: The results showed that the substitution of fermented citronella with different concentrations had no significant effect on the quality of semen. Volume, color, odor, $\mathrm{pH}$, consistency, concentration, mass sperms motility and motility of spermatozoa produced by thin-tailed ram fed with citronella waste as a substitute for basal feed is categorized as good.

Conclusions: The results showed that the substitution of fermented citronella with different concentrations had no significant effect on the quality of semen. Volume, color, odor, $\mathrm{pH}$, consistency, concentration, mass sperms motility and motility of spermatozoa produced by thin-tailed ram fed with citronella waste as a substitute for basal feed is categorized as good.

Keywords: Citronella; Semen quality; Waste

\section{PENDAHULUAN}

Domba adalah salah satu sumber daya genetik yang sangat potensial untuk dikembangkan. Domba memiliki beberapa keunggulan yaitu bersifat prolifik, daya adaptasi terhadap lingkungan dan penyakit tinggi, serta siklus produksi yang relatif lebih singkat [1]. Dalam upaya peningkatan populasi dan produksi domba, penggunaan pejantan unggul harus diperhatikan. Pejantan unggul adalah pejantan yang memiliki performa reproduksi yang tinggi, salah satunya ditandai dengan memiliki kualitas semen yang baik. Kualitas semen secara fisiologis sangat dipengaruhi oleh faktor nutrisi pakan [2,3]. Pakan yang mengandung nutrien seimbang akan membantu ternak untuk tumbuh dan berproduksi secara normal. Defisiensi pakan dapat menunda pubertas pada pejantan muda dan menghambat fungsi testikuler pada ternak jantan dewasa [4], sedangkan kekurangan energi dalam pakan berpengaruh terhadap sekresi gonadotropin, keterlambatan pubertas, penurunan libido, kerusakan pada epithel seminiferous, dan penurunan dan kualitas semen yang dihasilkan [5].

Perkembangan peternakan domba menghadapi banyak kendala terutama ketersediaan pakan yang berkesinambungan terutama pada musim kemarau [6]. Salah satu alternatif yang dapat ditempuh untuk memenuhi kebutuhan pakan adalah dengan pemanfaatan limbah pertanian maupun agroindustri, salah satunya limbah sereh wangi. Limbah sereh wangi dihasilkan dari proses penyulingan daun sereh wangi yang menghasilkan limbah sekitar $90 \%$ dari komposisi sereh wangi. Limbah hasil penyulingan sereh wangi masih memiliki kandungan nutrisi yang baik yaitu protein kasar $7 \%$, serat kasar $25,73 \%$, lemak kasar $2,30 \%$, energy 3353 (kkal/GE/kg), fospor $0,14 \%$, abu $7,19 \%$, dan kalsium 0,35\% [7]. Melihat besarnya potensi limbah sereh wangi dan kandungan nutrisinya, limbah sereh wangi sangat cocok digunakan sebagai pakan ruminansia sumber serat alternatif [8]. Kendala pemanfaatan limbah sereh wangi sebagai sumber serat alternatif adalah kandungan minyak atsiri berupa sitronella dan geraniol yang kemungkinan masih tersisa. Komponen minyak atsiri dalam sereh wangi tidak sepenuhnya aman dan kemungkinan bersifat karsinogenik. Pemberian minyak sereh wangi pada air minum tikus percobaan dengan dosis 50, 100, dan 200 ppm meningkatkan abnormalitas kromosom pada sumsum tulang belakang dan spermatosit primer [9]. Untuk meminimalisir residu minyak atsiri dan meningkatkan kecernaan limbah sereh wangi dilakukan proses penjemuran dan fermentasi. Proses penjemuran akan menguapkan komponen atsiri dalam limbah sereh wangi, sedangkan proses fermentasi mampu memecah fraksi serat kasar dan meningkatkan kadar protein pakan [10].

Penelitian penggunaan limbah sereh wangi fermentasi sebagai substitusi pakan basal memberikan hasil peningkatan performan pertumbuhan dan berat badan pada pada kerbau [8] dan domba [11], akan tetapi pengaruh penggunaan limbah sereh wangi fermentasi terhadap performan reproduksi khususnya kualitas semen belum diketahui. Penelitian ini dilakukan untuk 
mengetahui pengaruh penggunaan limbah sereh wangi fermentasi sebagai substitusi pakan basal terhadap kualitas semen domba ekor tipis.

\section{MATERI DAN METODE}

Penelitian ini dilaksanakan di kandang percobaan Laboratorium Lapangan Peternakan, Fakultas Pertanian, Universitas Syiah Kuala pada bulan Juni sampai dengan Agustus 2019. Domba percobaan yang digunakan adalah 4 ekor Domba Ekor Tipis (DET) jantan berumur 18 sampai 24 bulan dengan berat badan $25,4 \pm 1,01 \mathrm{~kg}$.

Alat-alat yang digunakan adalah mikroskop, Artificial Vagina dan seperangkat alat untuk pengujian kualitas semen. Pakan percobaan yang digunakan adalah limbah sereh wangi fermentasi, rumput gajah mini, rumput lapangan, lamtoro, pelet komersil dan dedak padi.

Rancangan percobaan yang digunakan adalah Rancangan Bujur Sangkar Latin (RBSL) dengan empat perlakuan dan empat ulangan. Periode perlakuan 14 hari dan periode adaptasi 7 hari. Perlakuan terdiri dari P0 (pakan basal tanpa substitusi limbah sereh wangi fermentasi), P1 (subtitusi pakan basal dengan limbah sereh wangi fermentasi $10 \%$ ), $\mathrm{P}_{2}$ (subtitusi pakan basal dengan limbah sereh wangi fermentasi 20\%), dan P3 (subtitusi pakan basal dengan limbah sereh wangi fermentasi $30 \%$ ). Komposisi nutrisi ransum ransum dari masing-masing perlakuan disajikan pada Tabel 1 .
Parameter yang diamati adalah kualitas sperma yang terdiri atas kualitas makroskopis dan mikroskopis sperma. Kualitas makroskopis meliputi volume, warna, bau, $\mathrm{pH}$ dan konsistensi sperma. Kualitas makroskopis sperma meliputi konsentrasi, gerakan massa dan motilitas sperma. Data warna, konsistensi dan gerakan massa diuji secara deskriptif, sedangkan data volume, konsentrasi dan motilitas dianalisis dengan

sidik ragam. Jika terdapat perbedaan antar perlakuan dilanjutkan dengan Uji Jarak Berganda Duncan (Duncan Multiple Range Test) [12].

\section{HASIL DAN PEMBAHASAN}

\section{Kualitas mikroskopis semen}

Evaluasi kualitas semen secara makroskopis meliputi volume, warna, bau konsistensi dan $\mathrm{pH}$ semen. Nilai rerata kualitas makroskopis semen segar domba ekor tipis yang diberikan limbah sereh wangi fermentasi sebagai substitusi pakan basal disajikan pada Tabel 2. Hasil penelitian menunjukkan bahwa pemberian limbah sereh wangi fermentasi sebagai substitusi pakan basal selama 14 hari perlakuan tidak berpengaruh terhadap kualitas makroskopis semen yang terdiri atas volume, warna, bau, konsistensi dan $\mathrm{pH}$ semen domba ekor tipis.

Hasil penelitian menunjukkan bahwa pemberian limbah sereh wangi fermentasi sebagai substitusi pakan basal selama 14 hari perlakuan tidak berpengaruh terhadap kualitas makroskopis semen yang terdiri atas

Tabel 1. Komposisi nutrisi ransum penelitian

\begin{tabular}{lrrrr}
\hline \multirow{2}{*}{ Komposisi Nutrisi } & \multicolumn{4}{c}{ Pakan Perlakuan } \\
\cline { 2 - 5 } & $\mathrm{P}_{0}$ & \multicolumn{1}{c}{$\mathrm{P}_{1}$} & $\mathrm{P}_{2}$ & \multicolumn{1}{c}{$\mathrm{P}_{3}$} \\
\hline Bahan Kering \% & 48,52 & 53,11 & 58,15 & 63,18 \\
Protein Kasar \% & 12,52 & 12,17 & 12,18 & 12,07 \\
Lemak Kasar \% & 4,68 & 4,72 & 4,78 & 4,84 \\
Serat Kasar \% & 20,57 & 20,72 & 20,80 & 20,83 \\
BETN \% & 52,10 & 52,34 & 52,27 & 52,38 \\
TDN \% & 63,43 & 63,32 & 63,47 & 63,59 \\
\hline
\end{tabular}

Keterangan : P0 = Kontrol (tanpa substitusi limbah sereh wangi fermentasi); P1 = substitusi limbah sereh wangi fermentasi 10\%; P2 = substitusi limbah sereh wangi fermentasi 20\%; P3 = substitusi limbah sereh wangi fermentasi $30 \%$ 
volume, warna, bau, konsistensi dan $\mathrm{pH}$ semen domba ekor tipis. Rataan volume sperma yang didapatkan selama penelitian berkisar antara 1.0 sampai 1,2 ml. Hasil penelitian yang diperoleh menunjukkan bahwa volume semen segar yang dihasilkan domba ekor tipis berada dalam kisaran normal volume ejakulat domba. Menurut Garner dan Hafez [13], standar volume sperma domba adalah $0,8-1,5$, sedangkan menurut Sekosi et al. [14] volume semen kambing setiap kali ejakulasi berkisar antara 0,5-1,5 ml. Volume semen segar hasil penelitian ini lebih baik jika dibandingkan hasil penelitian oleh Hersade [15] yang melakukan penelitian pada domba ekor tipis yang diberi pakan Indigofera $S p(0,53 \pm 0,12 \mathrm{ml})$ dan limbah tauge $(0,65 \pm 0,20)$. Hal ini kemungkinan disebabkan oleh kandungan nutrisi pakan penelitian yang cukup tinggi, kandungan protein kasar (12,07 - 12,52\%) dan TDN $(63,32-63,59 \%)$ dalam pakan penelitian lebih tinggi jika dibandingkan dengan standar kebutuhan untuk domba dengan berat badan 23-26 kg [16], yaitu TDN 55\% dan PK 9,6\%. Salas-Huetos et al. [3] menyatakan bahwa ransum yang cukup energi, protein, mineral, dan vitamin penting untuk pertumbuhan dan perkembangan ternak jantan muda. Volume semen hasil ejakulat juga dipengaruhi oleh umur kambing, frekuensi penampungan [17], cara pengambilan, berat badan ternak, status kesehatan [18], dan kualitas pakan [3].

Warna semen segar domba ekor tipis yang diberikan limbah sereh wangi fermentasi sebagai substitusi pakan basal selama 14 hari perlakuan adalah berwarna krem. Sesuai dengan Sekosi et al. [14] yang menyatakan bahwa warna semen segar kambing yang normal adalah putih hingga krem. Warna semen hasil penelitian termasuk dalam kategori normal karena tidak terdapat bercak kemerahan, coklat atau kehijauan. Menurut Ax et al. [17] semen berwarna kemerahan adalah tanda bahwa semen terkontaminasi oleh darah, warna coklat merupakan tanda bahwa darah yang mengkontaminasi semen sudah mengalami dekomposisi dan warna kehijauan merupakan tanda adanya bakteri pembusuk dalam semen. Menurut Feradis [19] warna semen dipengaruhi oleh konsentrasi spermatozoa, semakin tinggi konsentrasi spermatozoa maka warna semen akan semakin keruh.

Bau semen segar domba ekor tipis hasil penelitian adalah berbau khas semen. Menurut Feradis [19] dan Kusumawati et al. [20] bau semen yang normal adalah bau amis khas disertai bau dari hewan itu sendiri. Semen yang berbau busuk menunjukkan adanya kandungan nanah yang disebabkan infeksi saluran reproduksi hewan jantan.

Konsistensi semen segar domba ekor tipis yang dihasilkan adalah kental. Sesuai pendapat Zenichiro [21], semen yang baik kekentalannya hampir sama atau sedikit lebih kental dari susu, sedangkan semen yang jelek kekentalannya mendekati air kelapa. Menurut Feradis [19] semen yang kental memiliki konsentrasi spermatozoa yang tinggi. Konsistensi semen juga berhubungan dengan warna semen, warna semen yang semakin pudar menunjukkan konsentrasi spermatozoa yang semakin menurun.

Tabel 2. Kualitas makroskopis semen segar domba ekor tipis yang diberi limbah sereh wangi fermentasi sebagai substitusi pakan basal

\begin{tabular}{lcccc}
\hline \multirow{2}{*}{ Parameter } & \multicolumn{4}{c}{ Perlakuan } \\
\cline { 2 - 5 } & P0 & P1 & P2 & P3 \\
\hline Volume $(\mathrm{ml})$ & $1,0 \pm 0,2$ & $1,2 \pm 0,3$ & $1,0 \pm 0,1$ & $1,0 \pm 0,3$ \\
Warna* & Krem & Krem & Krem & Krem \\
Bau & Khas & Khas & Khas & Khas \\
Konsistensi* & Kental & Kental & Kental & Kental \\
Ph & $6,0 \pm 0,0$ & $6,3 \pm 0,5$ & $6,0 \pm 0,0$ & $6,0 \pm 0,0$ \\
\hline
\end{tabular}

Keterangan : $\quad$ P0 = Kontrol (tanpa substitusi limbah sereh wangi fermentasi); P1 = substitusi limbah sereh wangi fermentasi 10\%; P2 = substitusi limbah sereh wangi fermentasi 20\%; P3 = substitusi limbah sereh

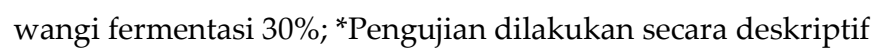


Derajat keasaman semen segar sangat menentukan status kehidupan spermatozoa di dalam semen. $\mathrm{pH}$ semen yang netral menunjukkan bahwa kelenjar assesoris (vesicularis, prostat dan bulbourethralis) yang mensekresikan plasma seminal berfungsi dengan baik. Rataan semen domba pada penelitian ini berkisar antara 6,0 sampai 6,3 sesuai dengan batasan normal semen segar. Menurut Garner dan Hafez [13] pH semen domba berkisar antara 5,9-7,3. Semakin tinggi atau rendah $\mathrm{pH}$ semen dari keadaan normal akan menyebabkan spermatozoa lebih cepat mengalami kematian [20]. Toelihere [22] menyatakan bahwa spermatozoa yang konsentrasinya tinggi biasanya memiliki $\mathrm{pH}$ yang sedikit asam. Perubahan $\mathrm{pH}$ ke arah yang lebih asam terjadi akibat penimbunan asam laktat hasil metabolisme anaerob dapat menurunkan tingkat kelangsungan hidup spermatozoa.

Penelitian ini menunjukkan bahwa nilai $\mathrm{pH}$ dari keempat perlakuan tidak menunjukkan adanya perbedaan dan berada dalam kisaran $\mathrm{pH}$ normal semen. Substitusi limbah sereh wangi pada pakan basal mampu mencukupi nutrisi sehingga dapat menunjang metabolisme spermatozoa secara normal tanpa menurunkan $\mathrm{pH}$ dari semen. Hal ini sesuai dengan Hersade [15] yang menyatakan $\mathrm{pH}$ semen yang normal menunjukkan pakan yang diberikan mengandung zat makanan yang dapat mendukung proses metabolisme spermatozoa secara normal.

\section{Kualitas mikroskopis semen}

Rerata kualitas mikrokopis semen segar domba ekor tipis dengan pemberian limbah sereh wangi fermentasi sebagai substitusi pakan basal selama 14 hari perlakuan disajikan dalam Tabel 3. Hasil penelitian menunjukkan bahwa pemberian limbah sereh wangi fermentasi sebagai substitusi pakan basal selama 14 hari perlakuan tidak berpengaruh terhadap kualitas mikroskopis semen yang terdiri atas konsentrasi, gerakan massa, dan motilitas sperma.

Nilai rerata konsentrasi semen pada penelitin ini ialah $2.820-3.490 \times 10^{6} / \mathrm{ml}$ atau berada pada kisaran normal semen domba. Menurut Garner dan Hafez [13], konsentrasi normal semen kambing atau domba berkisar 2.000-3.000 $\mathrm{x} 10^{6} / \mathrm{ml}$ dengan jumlah spermatozoa normal $80-95 \%$. Hasil analisis sidik ragam menunjukkan bahwa pemberian limbah sereh wangi fermentasi sebagai substitusi sebagian pakan basal tidak mempengaruhi konsentrasi semen segar domba ekor tipis. Hal ini disebabkan karena pakan yang diberikan memenuhi kebutuhan zat-zat makanan yang dibutuhkan untuk proses metabolisme, produksi, dan reproduksi. Menurut Salas-Huetos et al. [3], pakan yang disusun dengan berbagai macam bahan pakan mempunyai efek yang baik karena adanya sifat saling melengkapi kekurangan nutrisi suatu bahan pakan.

Gerak massa spermatozoa mempunyai kecenderungan untuk bergerak bersamasama ke satu arah membentuk gelombang yang tebal dan tipis, bergerak cepat atau lambat, tergantung konsentrasi spermatozoa hidup. Rataan gerakan massa pada hasil penelitian ini sangat bagus yaitu +++. Kondisi tersebut sesuai dengan pendapat Toelihere [22] bahwa gerakan massa spermatozoa yang normal adalah ++/+++. Gelombang yang terlihat pada penelitian ini berbentuk besar-

Tabel 3. Kualitas mikroskopis semen domba ekor tipis yang diberi limbah sereh wangi fermentasi sebagai substitusi pakan basal

\begin{tabular}{lcccc}
\hline \multirow{2}{*}{ Parameter } & \multicolumn{4}{c}{ Perlakuan } \\
\cline { 2 - 5 } & P0 & P1 & P2 & P3 \\
\hline Konsentrasi(x106/ml) & $3.490 \pm 78,80$ & $2.800 \pm 111,90$ & $2.820 \pm 113,38$ & $2.960 \pm 70,99$ \\
Gerakan Massa & +++ & +++ & +++ & +++ \\
Motilitas (\%) & $82,07 \pm 3,156$ & $82,24 \pm 3,232$ & $79,60 \pm 5,026$ & $82,56 \pm 2,711$ \\
\hline
\end{tabular}

Keterangan : $\mathrm{P} 0=$ Kontrol (tanpa pemberian limbah sereh wangi fermentasi); P1 = limbah sereh wangi fermentasi 10\%; P2 = limbah sereh wangi fermentasi 20\%; P3 = limbah sereh wangi fermentasi $30 \%$ 
besar, bergerak sangat cepat dan padat tidak tampak sperma secara individual, hal ini menunjukkan bahwa konsentrasi sperma aktif dalam semen lebih dari $90 \%$. Menutut Ax et al. [17] dan David et al. [4] hasil penilaian semen segar sangat bagus apabila terlihat sangat padat, gelombang yang terbentuk besar-besar dan bergerak sangat cepat. Tambing et al. [23] dan Malo et al. [24] mengatakan bahwa gerakan massa memberikan gambaran tentang daya gerak spermatozoa, semakin tebal dan besar gelombang serta pergerakannya yang semakin cepat menandakan kualitasnya baik. Domba yang diberikan limbah sereh wangi fermentasi sebagai substitusi pakan basal selama 14 hari perlakuan dapat mempertahankan konsentrasi dan gerakan massa spermatozoa.

Rerata motilitas semen domba ekor tipis yang diberikan limbah sereh wangi fermentasi sebagai pengganti sebagian pakan basal selama 14 hari perlakuan berada pada batasan normal yaitu berkisar antara 79,60-82,56\%. Hewan jantan dikatakan fertil jika mampu menghasilkan spermatozoa dengan motilitas antara $60-90 \%$ [13,24]. Hasil analisa ragam pada perlakuan pembeian limbah sereh wangi fermentasi sebagai substitusi pakan basal selama 14 hari perlakuan tidak berpengaruh terhadap motilitas domba ekor tipis. Hal ini diduga karena pakan yang diberikan mencukupi kebutuhan zat makanan sehingga memungkinkan metabolisme sperma berlansung secara optimal. Motilitas spermatozoa sangat tergantung oleh kandungan zat makanan yang terkandung didalam ransum. Menurut Garner dan Hafez [13], Nassan et al. [2], dan Salas-Huetos et al. [3] kandungan zat makanan pada ransum menjadi salah satu faktor yang mempengaruhi tingkat motilitas. Menurut Susilawati [25] penilaian gerakan individual dapat diketahui melalui pengamatan visual dimana pergerakan progresif atau gerakan aktif maju ke depan merupakan gerakan terbaik. Gerakan melingkar atau gerakan mundur sering merupakan tanda-tanda cold shock, gerakan ditempat sering terlihat pada semen tua dan apabila spermatozoa banyak yang berhenti bergerak maka dianggap mati.

Penggunaan limbah sereh wangi fermentasi sebagai substitusi pakan basal dengan konsentrasi $10-30 \%$ selama 14 hari perlakuan tidak menurunkan kualiatas sperma baik secara makroskopis maupun mikroskopis. Hal ini disebabkan karena secara umum penggunaan limbah sereh wangi fermentasi sebagai subtitusi pakan basal tidak menyebabkan penurunan kualitas pakan. Pengolahan limbah sereh wangi dengan fermentasi menyebabkan kecernaan bahan pakan tersebut menjadi lebih baik. Disamping itu penjemuran sebelum proses fermentasi telah menghilangkan atau meminimalisir komponen minyak atsiri dalam limbah sereh wangi. Proses penjemuran dapat menurunkan komponen atsiri dalam limbah sereh wangi karena selama proses penjemuran suhu fraksinasi komponen atsiri sereh wangi telah tercapai. Hal ini sesuai dengan pendapat Ferdayanti et al. [26] yang menyatakan bahwa komponen sitronela dan geraniol dalam sereh wangi dapat di fraksinasi dengan suhu $55^{\circ} \mathrm{C}$.

Meskipun sebagian penelitian melaporkan bahwa komponen minyak atsiri dalam sereh wangi bersifat tidak aman dan menyebabkan abnormalitas sperma [9], tetapi beberapa penelitian yang mempelajari hubungan minyak atsiri dan kualitas sperma melaporkan adanya peningkatan gerakan dan vitalitas sperma manusia yang mengkonsumsi kulit jeruk manis (Citrus sinensis) [27], sage (Salvia officinalis), oregano (Origanum vulgare), kayu putih (eucalyptus globulus) [28]. Meskipun beberapa jenis minyak atsiri mengandung senyawa antioksidan yang tinggi, akan tetapi penggunaan minyak atsiri dalam ransum tidak selalu memberikan hasil yang signifikan terhadap kulitas sperma. Penelitian yang dilaporkan Ouladsahebmadarek et al. [29] menyebutkan bahwa konsumsi bawang merah (Allium cepa), jahe (Zingiber officinale), Basil (Ocimum basilicum), kayu manis (Cinnamomum verum), kulit jeruk manis (Citrus sinensis), dan biji semangka (Citrullus lanatus) dalam jangka panjang tidak menyebabkan perubahan kualitas spermatozoa pada tikus.

Penambahan limbah sereh wangi fermentasi dalam pakan basal selama 14 hari perlakuan tidak menurunkan kualitas semen segar domba ekor tipis. Hal ini karena pemberian limbah sereh wangi fermentasi sebagai substitusi pakan basal dengan 
konsentrasi $10-30 \%$ masih mampu memenuhi kecukupan nutrisi untuk metabolism, pertumbuhan dan reproduksi domba. Hasil ini didukung dengan data penelitian ini yang menunjukkan peningkatan bobot badan ternak dengan rata-rata 128,75 g/hari. Hasil penelitian serupa dilaporkan oleh Nurhayu dan Warda [8] yang menyatakan bahwa penggunaan limbah sereh wangi pada ternak dapat meningkatkan produksi atau performan pertumbuhan kerbau.

Penggunaan limbah sereh wangi fermentasi dalam pakan basal selama 14 hari perlakuan tidak menurunkan kualitas semen segar domba ekor tipis. Proses spermatogenesis pada domba memakan waktu antara 47 sampai 48 hari [13], sehingga waktu perlakuan selama 14 hari tersebut terhitung relatif pendek sehingga tidak memberikan pengaruh terhadap kualitas semen yang dihasilkan. Hasil ini diperkuat dengan penelitian dari Kheradmand et al. [30] yang melakukan penelitian mengenai pengaruh perubahan nutrisi terhadap kualitas semen domba, perubahan nutrisi baru menunjukkan pengaruh terhadap kualitas semen domba pada perlakuan minggu ke-8. Perubahan komposisi nutrisi direspon secara cepat oleh tubuh, tetapi direspon secara lambat oleh organ reproduksi [2].

\section{KESIMPULAN}

Pemberian limbah sereh wangi fermentasi sebagai substitusi pakan basal selama 14 hari perlakuan tidak mempengaruhi kualitas semen domba ekor tipis baik secara makroskopis dan juga mikroskopis. Kualitas makroskopis dan mikroskopis semen segar yang dihasilkan oleh domba ekor tipis yang diberi pakan limbah sereh wangi fermentasi sebagai subtitusi pakan basal dengan konsentrasi 10$30 \%$ berada pada kisaran normal kualitas semen segar domba.

\section{KONFLIK KEPENTINGAN}

Penulis menayatakan tidak ada konflik kepentingan dengan pihak manapun terkait materi yang ditulis dalam naskah ini.

\section{DAFTAR PUSTAKA}

1. Direktorat Jenderal Peternakan. 2009. Buku Statistik Peternakan. Departemen Pertanian. Jakarta.

2. Nassan, F.L, J.E. Chavarro, and C. Tanrikut, 2018. Diet and men's fertility: does diet affect sperm quality? Fertil. Steril. 110: 570-577. Doi: 10.1016/j.fertnstert.2018. 05.025 .

3. Salas-Huetos, A., E.R. James, K.I. Aston, T.G. Jenkins, and D.T. Carrell. 2019. Diet and sperm quality: Nutrients, foods and dietary patterns. Reprod. Biol. 18: 219-224. Doi: 10.1016/j.repbio.2019.07.005.

4. David, I., P. Kohnke, P. Lagriffoul, O. Praud, F. Plouarboué, P. Degond and X. Druart. 2015. Mass sperm motility is associated with fertility in sheep. Anim. Reprod. Sci. 61: 75-81. Doi: 10.1016/ j.anireprosci.2015.08.006

5. Susilawati, T., Suyadi, Nuryadi, N, Isnaini, dan S. Wahyuningsih. 1993. Kualitas semen sapi Fries Holland dan Sapi Bali pada berbagai umur dan berat badan. Laporan Penelitian. Fakultas Peternakan, Universitas Brawijaya. Malang.

6. Yamin, M. C. Sumantri, S. Rahayu, M. Duldjaman, E.L. Aditia, M. Baihaqi and M.I.A. Dagong. 2009. Increasing local sheep growth performance through rapid selection at fattening farm. Proc. ISAI. 1: 57-60.

7. Sukamto, M. Djazuli dan D. Suheryadi. 2011. Serai wangi (Cymbopogon nardus L) sebagai penghasil minyak atsiri, tanaman konservasi dan pakan ternak. Dalam: Proc. ng Sem. Nas. Inovasi Perkebunan: 175-180.

8. Nurhayu, A. dan Warda. 2018. Pengaruh pemberian limbah sereh wangi hasil penyulingan minyak atsiri sebagai pakan ternak terhadap penampilan induk sapi bali. Biocelebes 12: 30-40. 
9. Kumar, S.S. and S.K. Kumar, 2013. Genotoxic effect of citronella oil in mice (Mus musculus). Cytogenetic toxicity of citronella oil in mice. Lambert Academic Publishing, India.

10.Sari, A.F., W. Manguwardoyo dan I. Sugoro. 2017. Degradasi ampas dan serai wangi segar (Cymbopogon nardus L) dengan metode in sacco pada kerbau fistula. Seminar Nasional Teknologi Peternakan dan Veteriner. pp. 119-125. Doi: 10.14334/Pros. Semnas.TPV-2017-p.119125.

11. Al Kindi, M., S. Wajizah dan D. Rahmadi. 2020. Performa domba local jantan yang diberikan limbah sereh wangi (Cymbopogon nardus) fermentasi sebagai pengganti sebagian pakan basal. JIM FP-PET 5(1): 213-224. Doi: 10.17969/jimfp.v5i1.13608.

12. Steel, R.G.D. dan J.H. Torrie. 1991. Prinsip dan Prosedur Statistika. PT. Gramedia Pustaka Utama. Jakarta.

13. Garner, D.L.and E.S.E. Hafez. 2008. Spermatozoa and seminal plasma. In: Reproduction. In: B. Hafez dan E.S.E Hafez, editor, Farm Animals $7^{\text {th }}$. Lea and Febiger, Philadelphia. p. 96-109.

14. Sekosi, P.P.P., E.D. Kusumawati, dan A.T.N. Krisnaningsih. 2016. Motilitas dan viabilitas semen segar kambing peranakan etawa (PE) dengan menggunakan pengencer cauda epididymal plasma (CEP2) pada lama dan suhu simpan yang berbeda. Jurnal Sains Peternakan 4(1): 3449.

15. Hersade, D.M. 2012. Gambaran kualitas spermatozoa domba garut dengan pemberian ransum komplit yang mengandung limbah tauge dan indigofera Sp. Skripsi. Fakultas Peternakan. Institut Pertanian Bogor. Bogor.
16. NRC. 2006. Nutrient Requirement of Sheep. National Academy Press, Washington.

17.Ax, R.L., M.R. Dally, B.A. Didion, R.W. Lenz, C.C. Love, D.D. Varner, B. Hafez and M. E Bellin. 2008 Artifical Insemination. In: Hafez E.S.E and B. Hafez, editor, Reproduction In Farm Animals ${ }^{7 e d}$. Blackwell Publishing. Australia.p. 365-375.

18. Santolaria, P., S. Vicente-Fiel, I. Palacín, E. Fantova, M.E. Blasco, M.A Silvestrean and J.L. Yániz. 2015. Predictive capacity of sperm quality parameters and sperm subpopulations on field fertility after artificial insemination in sheep. Anim. Reprod. Sci. 163: 82-88. Doi: 10.1016/ j.anireprosci.2015.10.001.

19. Feradis. 2007. Karakteristik sifat fisik semen domba St. croix. Jumal Petemakan. 4: 1-5. Doi: http://dx.doi.org/10.24014/jupet .v4i1.254.

20. Kusumawati, E.D., H. Leondro, A.T.N. Krisnaningsih, T. Susilawati, N. Isnaini and R. Widhad. 2016. Pengaruh suhu dan lama simpan semen segar terhadap motilitas dan abnormalitas spermatozoa kambing peranakan etawa (PE). Proc. Sem. Nas. Hasil Penelitian. p.199- 208.

21.Zenichiro. 2002. Teknologi Prosesing Semen Beku pada Sapi. Balai Besar Inseminasi Buatan Singosari, Malang.

22. Toelihere. 1993.Inseminasi Buatan pada Ternak. Angkasa. Bandung.

23. Tambing, S.N., M.R. Toelihere, T.L. Yusuf, \& I.K. Sutama. 2000. Pengaruh gliserol dalam pengencer Tris terhadapkualitas semen beku kambing Peranakan Etawah. JITV. 5:1-8.

24. Malo, A.F., J.J. Garde, A.J. Soler, A.J. Garcia, M. Gomendio and E.R. Roldan. 2004. Male fertility in natural populations 
of red deer is determined by sperm velocity and the proportion of normal spermatozoa. Biol. Reprod. 72: 822-829. Doi: 10.1095/ biolreprod. 104.036368.

25. Susilawati, T. 2005. Tingkat keberhasilan kebuntingan dan ketepatan jenis kelamin hasil inseminasi buatan menggunakan semen beku sexing pada sapi Peranakan Ongole. Jurnal Produksi Ternak 7: 161- 167. Doi: 10.21776/ub.jiip.2019.029.02.10.

26. Ferdayanti, M., H. Sastrohamidjojo dan $R$. Riyanto. 2014, Pemekatan sitronela dalam minyak sereh wangi (Cymbopogon nardus L.) dengan fraksinasi distilasi dan identifikasi menggunakan KG-SM. Indo. J. Chem. Res. 2: 28-34. Doi: 10.20885/ijcr.vol1.iss2.art4.

27. Khaki, A., F. Fathiazad, M. Nouri, A.A. Khaki, Z. Ghanbari, M. Ghanbari, E. Ouladsahebmadarek, L. Javadi and L. Farzadi. 2011. Anti-oxidative effects of citro flavonoids on spermatogenesis in rat. Afr. J. Pharm. Pharmacol. 5: 721-725. Doi: 10.5897/AJPP11.277.

28. Mbaye, M.M., B. El Khalfi, B. Addoum, P.D. Mar, B. Saadani, N. Louanjli and A. Soukri. 2019. The effect of supplementation with some essential oils on the mobility and the vitality of human sperm. The Scientific World Journal. Doi: 10.1155/2019/ 4878912.

29. Ouladsahebmadarek, E, G.S. Giasi, A. Khaki, Y. Ahmadi, L. Farzadi, A. Ghasemzadeh and K. Hajizade. 2016 The Effect of compound herbal remedy used in male infertility on spermatogenesis and pregnancy rate. IJWHR 4: 185-188. Doi: 10.15296/ijwhr. 2016.41.

30. Kheradmand, A., H. Babaei and R.A. Batavani, 2006. Effect of improved diet on semen quality and scrotal circumference in the ram. Veterinarski arhiv 76 (4): 333-341. 